\title{
Roche pledges independence to new institute
}

Washington. The Swiss pharmaceutical company Hoffman-La Roche, still facing controversy over its decision last November to transfer the renowned Roche Institute of Molecular Biology (RIMB) from Nutley, New Jersey to Stanford, California, has promised that the relocated institute will continue to enjoy freedom to pursue basic research.

Roche is still trying to find a director for the new institute - which will also have new staff and a new mission in genomics but is "not going to interfere after that", says Jurgen Drews, the company's president of international research and development. $\mathrm{He}$ promises to keep the charter that guaranteed the independence of the old institute.

But scientists at Nutley - almost all of whom are likely to leave, despite Roche's suggestion that they can "discuss the possibility of remaining with the RIMB" when the new director is appointed - say that the concept of the institute's independence has been permanently shattered by Roche's actions. "Our charter was supposed to protect us from short-term changes in corporate outlook," says one senior researcher who asked not to be named. "It didn't."

The institute was established by Roche at Nutley in 1967, and has developed a worldwide reputation through its successful cloning of interferon and a host of other scientific advances.

Many of its researchers claim that the decision to move the institute is the result of a combination of Drews' personal preference for California and its sunshine over the New Jersey suburbs of New York, as well as a reshuffling of research resources following Roche's \$5.3-billion acquisition of the Stanford-based drugs company Syntex.

The closure of the Nutley institute will be counted, the researchers say, among 5,000 job cuts that Roche said would come from post-merger rationalization. Severance costs at Nutley will be itemized in Roche's accounts as Syntex acquisition costs.

But, given that changes were in the wind even before the Syntex deal, another powerful element in Roche's decision appears to have been its failure, after more than a year of trying, to attract a suitably qualified geneticist to replace Herbert Weissbach, who is retiring as director of the institute. Drews has wanted to reorientate the institute towards genomics for some time, and is now hoping that the promise of hand-picked staff at a new site will make it easier to attract the right person.

Researchers at Nutley are angry that what they regarded as their tenure at the institute has been abrogated, even though they have been offered a severance package of one month's salary for each year of service, as well as transition grants to enable their research to continue until they find new sources of support.
But Shirley Tilghman, a professor of life science at Princeton University who chairs an external board of scientific advisers to the director of the institute, describes Roche's offer as "fair and reasonable", and says the board has tried to ensure the well-being of RIMB scientists. She admits that the sudden decision to move the institute "was shocking to those of us who live and work in academic science". But Tilghman feels that Roche was acting "within its rights" in deciding to change the focus of the institute.

The new focus will depend largely on the new director. "We're looking for someone who is interested in developing a vision of what such a new institute could be," says Drews. But he promises that the Stanford centre will not just be another genomics centre. "It is post-genomics: the science after we have the sequence of the genome," he says, adding that funding of the institute will remain about $\$ 20$ million a year.

Drews says that the concept of a broadly based molecular biology institute made sense in the $1960 \mathrm{~s}$, when the subject was relatively new. "Today it is different, it is mainstream science. The mission is a little out of date, and we felt it needed a change."

But scientists soon to lose their posts at Nutley feel insulted by Drews' logic, as they see themselves already at the forefront of efforts to understand the function of genes. "They [Roche] don't seem to understand what genomics is," says one. "You need genomics people to sequence the genome, and to do gene function work you need broadly based molecular biologists."

Colin Macilwain

\section{Congress seeks regulation controls}

Washington. The new Republican-led US Congress moved swiftly last week on its pledge to reduce the size and influence of the federal government, introducing three bills on the session's opening day designed to limit 'unfunded mandates' imposed on states, local governments and businesses.

These 'mandates' refer to environmental, safety, health and other regulations that are required by federal law but do not include federally appropriated money for localities to carry them out.

Republicans have declared the elimination of unfunded mandates to be one of their priorities, and a bill drafted by Senator Dirk Kempthorne of Idaho was the first introduced in the Senate. But the issue is not strictly partisan. The proposed legislation has Democratic co-sponsors, as well as the support of President Bill Clinton.

Furthermore, although environmentalists fear that this marks the beginning of a larger campaign to weaken environmental legislation in the new Congress, the proposed bills are less radical than demands in the Republicans' Contract with America and elsewhere. For example, they would not apply to laws already on the books - a particular fear of environmentalists.

According to the proposed legislation, if Congress imposes a mandate, such as a new drinking water standard, on a state or local government, it must also appropriate funds. If federal money is not provided, the mandate must be scaled back to match available funds, or Congress must take a separate vote to impose the mandate.

Any new law expected to place a significant financial burden on local governments or businesses would require the Congressional Budget Office to estimate those costs before the law is passed.

Estimating the cost of new regulations is

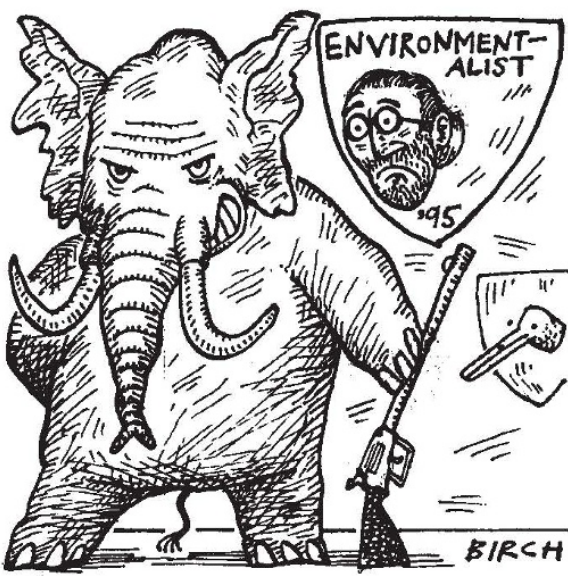

notoriously difficult, and making such estimates mandatory could therefore bog down the regulatory process. Restricting unfunded mandates may also lead to fewer federal regulations, as Congress would have to pay more of the regulations' costs.

If federal mandates are scaled back, some state and local governments may relax their own environmental regulations to attract businesses, becoming what Blakeman Early, a Washington consultant and former lobbyist for the Sierra Club on clean-air legislation, calls "pollution havens".

Environmentalists will face bigger challenges in this new Congress, but the issue of unfunded mandates carries much symbolic weight with state governors and mayors, who have long complained about them. Republicans are eager to win the governors' support for an amendment to the US constitution requiring a balanced federal budget; such an amendment would have to be approved by three-quarters of the states. The bills introduced last week are therefore expected to pass quickly, perhaps by the end of the month. 